\title{
HEALTH RISKS PHYSIOPROPHYLAXIS THROUGH PHYSICAL ACTIVITY IN PEOPLE AGED 50+ FROM POLAND AND UKRAINE
}

\section{FIZJOPROFILAKTYKA ZAGROŻEŃ ZDROWIA PRZEZ AKTYWNOŚĆ FIZYCZNĄ OSÓB 50+ Z POLSKI I UKRAINY}

\author{
Zofia Kubińska ${ }^{1(\mathrm{~A}, \mathrm{~B}, \mathrm{D}, \mathrm{E}, \mathrm{F})}$, Kamil Zaworski $^{1(\mathrm{~A}, \mathrm{~B}, \mathrm{C}, \mathrm{D}, \mathrm{E}, \mathrm{F})}$, Igor Mysula $^{1(\mathrm{~B}, \mathrm{E}, \mathrm{F})}$ \\ ${ }^{1}$ Department of Physiotherapy, Pope John Paul II State School of Higher Education in Biała Podlaska, Poland
}

Authors' contribution Wkład autorów:

A. Study design/planning zaplanowanie badań B. Data collection/entry zebranie danych C. Data analysis/statistics dane - analiza i statystyki D. Data interpretation interpretacja danych E. Preparation of manuscript przygotowanie artykułu F. Literature analysis/search wyszukiwanie $\mathrm{i}$ analiza literatury G. Funds collection zebranie funduszy
Tables: 6

Figures: 0

References: 17

Submitted: 2021 Jun 17

Accepted: 2021 Aug 3

\section{Summary}

Background. Studies of people aged 50+ undertaking physical activity show the possibility to delay and mitigate the ailments associated with the aging process. The aim of this study was to present the physioprophylaxis of the aging process in people aged 50 and above from the Lublin Voivodeship in Poland and the Ternopil region in Ukraine through physical activity, taking into account health condition, regularity of check-ups, sources of knowledge, forms of activity, age and the level of education.

Material and methods. The study group involved 121 people from the Lublin Voivodeship and 102 people from the Ternopil region. A questionnaire designed by the authors was used in the study.

Results. In the group of respondents from the Lublin Voivodeship, younger age was correlated with more frequent participation in power walks, dancing, Nordic walking, jogging, active tourism as well as strength and flexibility training $(p<0.05)$. Better health condition was observed in those individuals who reported more frequent power walks, cycling, working on the plot, Nordic walking, active tourism and strength training $(p<0.05)$. Statistically significant regularity of check-ups was reported only in individuals who practiced cycling $(p<0.05)$. No correlations between these variables were reported in the study group from Ternopil $(p>0.05)$.

Conclusions. The analysis of the obtained data showed that study participants from Poland more often engage in physical activity and perceive their health condition as good more frequently than the respondents from Ukraine. Age and health status were the factors influencing the frequency and choice of physical activity forms undertaken by the respondents.

Keywords: physioprophylaxis, physical activity, elderly, health

\section{Streszczenie}

Wprowadzenie. Badania osób 50+ podejmujących aktywność fizyczną ukazują możliwość opóźnienia i łagodzenia dolegliwości procesu starzenia się. Celem pracy jest przedstawienie fizjoprofilaktyki procesu starzenia się osób 50+ z Lubelszczyzny i Tarnopola na Ukrainie poprzez podejmowaną aktywność fizyczną z uwzględnieniem stanu zdrowia, systematyczności badań kontrolnych, źródeł wiedzy, form aktywności, wieku i wykształcenia.

Materiał i metody. Grupa badanych z województwa lubelskiego liczyła 121 osób, a z okregu Tarnopola 102 osoby. W badaniach sondażowych wykorzystano autorską ankietę.

Wyniki. W grupie badanych $\mathrm{z}$ województwa lubelskiego młodszy wiek skorelowany był z częstszym uprawianiem marszobiegu, tańca, nornic walkingu, biegania, turystyki aktywnej oraz ćwiczeń siłowych i gibkościowych $(\mathrm{p}<0,05)$. Odnotowano także związek lepiej ocenianego stanu zdrowia z częstszym uprawianiem marszobiegu, jazdy na rowerze, pracy na działce, nordic walkingu, turystyki aktywnej oraz ćwiczeń siłowych $(\mathrm{p}<0,05)$. Regularne wykony wanie badań kontrolnych było związane jedynie z częstszym uprawianiem jazdy na rowerze $(p<0,05)$. W grupie ankietowanych z Tarnopola nie odnotowano żadnych korelacji między badanymi zmiennymi $(p>0,05)$.

Wnioski. Analiza otrzymanych danych ukazała, że badani z Polski częściej podejmuja aktywność fizyczną oraz lepiej oceniają swój stan zdrowia niż ankietowani z Ukrainy. Wiek oraz stan zdrowia były czynnikami wpływającymi na częstość uprawiania oraz wybór form aktywności fizycznej przez ankietowanych.

Słowa kluczowe: fizjoprofilaktyka, aktywność fizyczna, osoby starsze, zdrowie 


\section{Introduction}

The process of aging involves unfavorable changes in the structure and functions of organs and systems which are universal, gradual, spontaneous and irreversible. The deterioration starts right after the period of physiological growth and puberty, i.e. at the age of 20-25. Aging is associated with changes within all areas of health: decrease in physical agility, mental capacity and social activity. For some aging means approaching the end of life and for others, aging gives life a new meaning [1].

In the literature on the subject, physical activity is defined as a human health behavior that has an influence on the mitigation of adverse changes of the progressing and inevitable aging process. This is why middleaged people $(50+)$, that is individuals in the age preceding the effects of the involutional processes, should engage in some form of physical exercise. Study results indicate that apart from pathological aging, regular (positive) aging also occurs. Involutional processes may be delayed or mitigated through physical activity. According to Wieczorkowska-Tobis, the aging process itself does not cause diseases. Yet, it expressly facilitates their occurrence [2]. Inhibiting aging processes requires health awareness, promoting a healthy lifestyle and introducing gerontological (etiologic, protective and corrective) prevention [3].

According to the Polish Central Statistical Office in 2016 in Poland, among the people who were above 60 years old and regularly participating in sport and physical recreation, $10.6 \%$ were women and $10.9 \%$ men. $40.5 \%$ of the elderly took exercise for pleasure and $31.7 \%$ for health reasons following doctor's recommendations [4]. Among seniors-pensioners from Ukraine, the percentage of people doing any kind of sport or physical activity amounted to $17.6 \%$ men and $16.8 \%$ women [5].

According to the definition suggested by the Polish National Council of Physiotherapists (2019), physioprophylaxis is a behavior consisting in physical activity, health education, reduction of risk factors and functional diagnostics aimed at avoiding or inhibiting the development of functional problems and diseases, with the goal to counteract, delay, inhibit or withdraw the adverse consequences of incorrect lifestyle, involutional changes and disease processes [6].

The aim of this study was to present the physioprophylaxis of the aging process in people aged 50 and above from the Lublin Voivodeship in Poland and the Ternopil region in Ukraine through physical activity, taking into account health condition, regularity of check-ups, sources of knowledge, forms of activity, age and the level of education.

\section{Material and methods}

Audience study was conducted in 2019 among people over 50 years old who live in the Lublin Voivodeship in Poland and the Ternopil region in Ukraine. The questionnaire designed by the authors included metrics (age, sex, education and place of living) and multiple choice questions concerning self-assessment of health, regularity of check-ups, used sources of knowledge about the physioprophylaxis and forms of undertaken physical activity.

The statistical analysis was conducted by means of the IBM SPSS 25.0 packet with ExactTests module accurate tests. Phi and Kramer tests were used for this paper (for questions with nominal scales). In the case of tables, when the condition of minimal suspected quantity was not fulfilled, the chi-squared Fisher's exact test was performed. In the tests, the significance level was assumed at $\mathrm{p}<0.05$.

\section{Results}

The study group from Poland consisted of 121 people - 85 (70.2\%) women and $36(29.8 \%)$ men. The mean age amounted to $66.9 \pm 8.2$ years. The group from Ukraine consisted of 102 people $-76(74.5 \%)$ women and 26 $(25.5 \%)$ men. The mean age amounted to $68.4 \pm 6.7$ years. The detailed demographics were presented in Table 1. 
Table 1. Demographic data of study participants from Poland and Ukraine

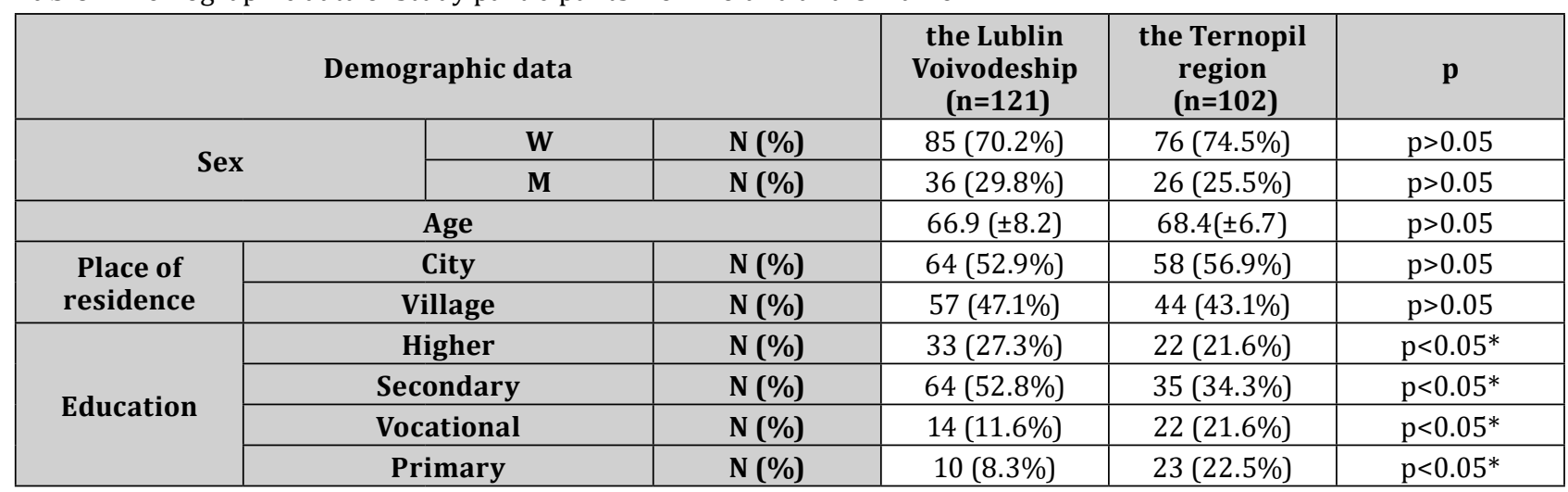

Notes: *Statistically significant $(\mathrm{p}<0.05)$.

The self-assessment of health carried out by the study participants showed that study participants from Poland perceived their health as good more frequently than the study participants from Ternopil, Ukraine. The correlation between the variables is statistically significant and is distinguished by a distinct strength of the correlation (Table 2).

Table 2. The self-assessment of the health of study participants from Poland and Ukraine

\begin{tabular}{|c|c|c|c|c|c|c|}
\hline \multicolumn{2}{|c|}{ Self-assessment of health } & \multirow{2}{*}{$\begin{array}{c}\begin{array}{c}\text { the Lublin } \\
\text { Voivodeship } \\
\text { (n=121) }\end{array} \\
12(9.9 \%)\end{array}$} & \multirow{2}{*}{ 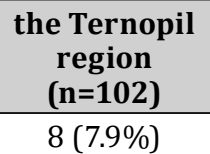 } & \multirow{4}{*}{$\begin{array}{c}\text { Kramer V } \\
0.486\end{array}$} & \multirow{4}{*}{$\begin{array}{c}\text { Chi-Squared } \\
\\
52.284\end{array}$} & \multirow{4}{*}{$\begin{array}{c}\mathbf{p} \\
0.001^{*}\end{array}$} \\
\hline Very good & N (\%) & & & & & \\
\hline Good & N (\%) & $83(68.6 \%)$ & $59(57.8 \%)$ & & & \\
\hline Poor & N (\%) & $25(20.7 \%)$ & $33(32.4 \%)$ & & & \\
\hline Very poor & N (\%) & $1(0.8 \%)$ & $2(1.6 \%)$ & & & \\
\hline
\end{tabular}

Notes: *Statistically significant $(\mathrm{p}<0.05)$.

The obtained data showed that study participants from the Lublin Voivodeship performed health check-ups more regularly than the participants from Ternopil (39.7\% - Poland, 20.6\% - Ukraine) The correlation between the variables is statistically significant and is distinguished by the pronounced strength of the correlation (Table 3).

Table 3. The regularity of check-ups conducted by the study participants

\begin{tabular}{|c|c|c|c|c|c|c|}
\hline \multicolumn{2}{|c|}{ Conducting check-ups } & $\begin{array}{l}\text { the Lublin } \\
\text { Voivodeship }\end{array}$ & $\begin{array}{l}\text { the Ternopil } \\
\text { region }\end{array}$ & Kramer V & Chi-Squared & $\mathbf{p}$ \\
\hline Systematically & N (\%) & $48(39.7 \%)$ & $21(20.6 \%)$ & \multirow{5}{*}{0.324} & \multirow{5}{*}{23.150} & \multirow{5}{*}{$0.001^{*}$} \\
\hline $\begin{array}{c}\text { Rather } \\
\text { systematically }\end{array}$ & N (\%) & $35(28.9 \%)$ & $37(36.3 \%)$ & & & \\
\hline From time to time & N (\%) & $23(19.0 \%)$ & $21(20.6 \%)$ & & & \\
\hline Rarely & $\mathrm{N}(\%)$ & $11(9.1 \%)$ & $14(13.7 \%)$ & & & \\
\hline Not at all & N (\%) & $4(3.3 \%)$ & $9(8.8 \%)$ & & & \\
\hline
\end{tabular}

Notes: *Statistically significant $(\mathrm{p}<0.05)$.

The sources of knowledge on the topic of physioprophylaxis of health threats showed by both groups were slightly different. The respondents from Poland most often indicated doctors, mass media, family, acquaintances, web pages and physiotherapists as the sources of knowledge, while the study participants from Ternopil most often indicated doctors, nurses and mass media. Exclusively in the case of the above-mentioned responses, the correlations were statistically significant (Table 4). 
Table 4. Sources of knowledge on the topic of physioprophylaxis of health threats

\begin{tabular}{|c|c|c|c|c|c|c|}
\hline \multicolumn{2}{|c|}{ Sources of knowledge } & $\begin{array}{c}\text { the Lublin } \\
\text { Voivodeship } \\
\text { (n=121) }\end{array}$ & $\begin{array}{c}\text { the Ternopil } \\
\text { region } \\
\text { (n=102) }\end{array}$ & Phi & Chi-Squared & p \\
\hline Medical journals & $\mathbf{N}(\%)$ & $26(21.5 \%)$ & $6(5.9 \%)$ & 0.074 & 1.207 & 0.272 \\
\hline Health journals & $\mathbf{N}(\%)$ & $26(21.5 \%)$ & $3(2.9 \%)$ & 0.144 & 4.561 & $0.033^{*}$ \\
\hline The internet & $\mathbf{N}(\%)$ & $67(55.4 \%)$ & $2(1.9 \%)$ & 0.362 & 29.034 & $0.001^{*}$ \\
\hline Mass-media & $\mathbf{N}(\%)$ & $85(70.2 \%)$ & $17(16.7 \%)$ & 0.210 & 9.738 & $0.002^{*}$ \\
\hline Tabloids & $\mathbf{N}(\%)$ & $10(8.3 \%)$ & 0 & 0.131 & 3.815 & 0.051 \\
\hline Acquaintances & $\mathbf{N}(\%)$ & $71(58.7 \%)$ & $11(10.8 \%)$ & 0.231 & 11.753 & $0.001^{*}$ \\
\hline Family & $\mathbf{N}(\%)$ & $72(59.5 \%)$ & $11(10.8 \%)$ & 0.236 & 12.276 & $0.001^{*}$ \\
\hline Doctor & $\mathbf{N}(\%)$ & $90(74.4 \%)$ & $43(42.2 \%)$ & 0.157 & 5.418 & $0.020^{*}$ \\
\hline Nurse & $\mathbf{N}(\%)$ & $19(15.7 \%)$ & $17(16.7 \%)$ & 0.205 & 9.258 & $0.002^{*}$ \\
\hline Physiotherapist & $\mathbf{N}(\%)$ & $49(40.5 \%)$ & $1(0.9 \%)$ & 0.302 & 20.140 & $0.001^{*}$ \\
\hline
\end{tabular}

Notes: ${ }^{*}$ Statistically significant $(\mathrm{p}<0.05)$.

Physical activity undertaken by the study participants as a way of preventing health problems had many forms. Study participants from Poland usually worked in the plot, cycled, danced, did gymnastics, engaged in Nordic walking and power walks. Study participants from Ternopil most commonly worked in the plot and did gymnastics, cycled, or power walked to a much lesser extent. The correlations were statistically significant (Table 5).

Table 5. Forms of physical activity undertaken by study participants from Poland and Ukraine (n=223)

\begin{tabular}{|c|c|c|c|c|c|c|}
\hline \multicolumn{2}{|c|}{ Types of physical activity } & $\begin{array}{c}\text { the Lublin } \\
\text { Voivodeship } \\
\text { (n=121) }\end{array}$ & $\begin{array}{c}\text { the Ternopil } \\
\text { region } \\
\text { (n=102) }\end{array}$ & Phi & Chi-Squared & p \\
\hline Power walking & $\mathbf{N}(\%)$ & $55(45.5 \%)$ & $6(5.9 \%)$ & 0.235 & 12.240 & $0.001^{*}$ \\
\hline Gymnastics & $\mathbf{N}(\%)$ & $62(51.2 \%)$ & $8(7.8 \%)$ & 0.341 & 12.204 & $0.001^{*}$ \\
\hline Bicycle & $\mathbf{N}(\%)$ & $104(85.9 \%)$ & $7(6.9 \%)$ & 0.538 & 63.978 & $0.001^{*}$ \\
\hline Dancing & $\mathbf{N}(\%)$ & $63(52.1 \%)$ & $5(4.9 \%)$ & 0.292 & 18.781 & $0.001^{*}$ \\
\hline Plot & $\mathbf{N}(\%)$ & $110(90.9 \%)$ & $21(20.6 \%)$ & 0.291 & 18.701 & $0.001^{*}$ \\
\hline Nordic walking & $\mathbf{N}(\%)$ & $62(51.2 \%)$ & $3(2.9 \%)$ & 0.322 & 22.943 & $0.001^{*}$ \\
\hline Jogging & $\mathbf{N}(\%)$ & $52(42.9 \%)$ & $3(2.9 \%)$ & 0.276 & 16.884 & $0.001^{*}$ \\
\hline Active tourism & $\mathbf{N}(\%)$ & $53(43.8 \%)$ & $5(4.9 \%)$ & 0.244 & 13.130 & $0.001^{*}$ \\
\hline Strength training & $\mathbf{N}(\%)$ & $54(44.6 \%)$ & $4(3.9 \%)$ & 0.267 & 15.754 & $0.001^{*}$ \\
\hline $\begin{array}{c}\text { Flexibility } \\
\text { training }\end{array}$ & $\mathbf{N}(\%)$ & $52(42.9 \%)$ & $5(4.9 \%)$ & 0.239 & 12.611 & $0.001^{*}$ \\
\hline
\end{tabular}

Notes: *Statistically significant data $(\mathrm{p}<0.05)$.

Table 6 presents the correlation between the form and frequency of undertaken physical activities and the age, level of education, health status and regularity of check-ups. The correlation coefficient (marked with the symbol *) shows an inverse correlation between the marked variables. In the group from the Lublin Voivodeship, younger age was correlated with a more frequent participation in power walks, dancing, Nordic walking, jogging, active tourism as well as strength and flexibility training $(\mathrm{p}<0.05)$. Better health condition was observed in those individuals who reported more frequent power walks, cycling, working on the plot, Nordic walking, active tourism and strength training $(\mathrm{p}<0.05)$. Statistically significant regularity of check-ups was reported only in individuals who practiced cycling $(\mathrm{p}<0.05)$. No correlations between the variables were reported in the group from Ternopil ( $\mathrm{p}>0.05)$. 
Table 6. The correlation between the form of undertaken physical activity and age, level of education, health status and regularity of check-ups

\begin{tabular}{|c|c|c|c|c|c|c|c|c|c|}
\hline \multirow{2}{*}{$\begin{array}{l}\text { Types of } \\
\text { physical } \\
\text { activity }\end{array}$} & \multirow[b]{2}{*}{ Group } & \multicolumn{2}{|l|}{ Age } & \multicolumn{2}{|c|}{ Education } & \multicolumn{2}{|c|}{ State of health } & \multicolumn{2}{|c|}{ Check-ups system } \\
\hline & & $\begin{array}{c}\text { Correlation } \\
\text { coefficient }\end{array}$ & $\mathbf{p}$ & $\begin{array}{c}\text { Correlation } \\
\text { coefficient }\end{array}$ & $\mathbf{p}$ & $\begin{array}{c}\text { Correlation } \\
\text { coefficient }\end{array}$ & p & $\begin{array}{c}\text { Correlation } \\
\text { coefficient }\end{array}$ & $\mathbf{p}$ \\
\hline \multirow{2}{*}{$\begin{array}{c}\text { Power } \\
\text { walking }\end{array}$} & Lublin & $-0.226^{*}$ & 0.004 & 0.011 & 0.886 & $0.169 *$ & 0.031 & -0.009 & 0.910 \\
\hline & Ternopil & -0.149 & 0.259 & -0.122 & 0.357 & 0.115 & 0.388 & 0.080 & 0.546 \\
\hline \multirow{2}{*}{ Gymnastics } & Lublin & -0.134 & 0.089 & 0.089 & 0.258 & -0.137 & 0.083 & -0.028 & 0.720 \\
\hline & Ternopil & -0.216 & 0.101 & -0.194 & 0.141 & 0.178 & 0.177 & 0.023 & 0.864 \\
\hline \multirow{2}{*}{ Bicycle } & Lublin & -0.037 & 0.638 & 0.092 & 0.243 & $0.261^{*}$ & 0.001 & $0.171^{*}$ & 0.030 \\
\hline & Ternopil & -0.185 & 0.161 & -0.219 & 0.096 & 0.144 & 0.276 & 0.109 & 0.410 \\
\hline \multirow{2}{*}{ Dancing } & Lublin & $-0.268^{*}$ & 0.001 & 0.004 & 0.960 & -0.122 & 0.122 & 0.001 & 0.991 \\
\hline & Ternopil & -0.254 & 0.053 & -0.061 & 0.647 & 0.207 & 0.116 & 0.169 & 0.200 \\
\hline \multirow{2}{*}{ Plot } & Lublin & -0.130 & 0.099 & -0.093 & 0.241 & $-0.246^{*}$ & 0.002 & 0.083 & 0.295 \\
\hline & Ternopil & 0.131 & 0.321 & 0.042 & 0.750 & 0.076 & 0.565 & 0.178 & 0.177 \\
\hline \multirow{2}{*}{$\begin{array}{c}\text { Nordic } \\
\text { walking }\end{array}$} & Lublin & $-0.176^{*}$ & 0.025 & 0.027 & 0.732 & $-0.172^{*}$ & 0.029 & 0.077 & 0.125 \\
\hline & Ternopil & -0.119 & 0.368 & 0.031 & 0.817 & 0.157 & 0.234 & 0.157 & 0.345 \\
\hline \multirow{2}{*}{ Jogging } & Lublin & $0.280^{*}$ & 0.000 & 0.000 & 0.998 & $-0.165^{*}$ & 0.036 & -0.011 & 0.982 \\
\hline & Ternopil & -0.119 & 0.368 & 0.031 & 0.817 & 0.157 & 0.234 & 0.125 & 0.345 \\
\hline \multirow{2}{*}{$\begin{array}{c}\text { Active } \\
\text { tourism }\end{array}$} & Lublin & $-0.221 *$ & 0.005 & -0.006 & 0.938 & $-0.196^{*}$ & 0.013 & -0.008 & 0.918 \\
\hline & Ternopil & -0.254 & 0.053 & -0.061 & 0.647 & 0.207 & 0.116 & 0.169 & 0.200 \\
\hline \multirow{2}{*}{$\begin{array}{l}\text { Strength } \\
\text { training }\end{array}$} & Lublin & $-0.284^{*}$ & 0.0000 & -0.068 & 0.393 & $-0.166^{*}$ & 0.034 & -0.044 & 0.577 \\
\hline & Ternopil & -0.165 & 0.212 & 0.036 & 0.787 & 0.183 & 0.165 & 0.148 & 0.263 \\
\hline \multirow{2}{*}{$\begin{array}{c}\text { Flexibility } \\
\text { training }\end{array}$} & Lublin & $-0.178^{*}$ & 0.023 & -0.045 & 0.570 & -0.138 & 0.080 & -0.044 & 0.580 \\
\hline & Ternopil & -0.145 & 0.274 & -0.061 & 0.647 & 0.091 & 0.494 & 0.063 & 0.637 \\
\hline
\end{tabular}

Notes: *Statistically significant data $(\mathrm{p}<0.05)$.

\section{Discussion}

The results of the $7^{\text {th }}$ edition of SHARE: 50+ study in Europe presenting the health status of men and women aged 50+ revealed an unfavorable image of the health situation of the 50+ generation in Poland compared to six other European countries. Subjectively, both men and women were on average three times more likely to assess their health status as bad than the residents of the other EU countries. Similarly, the percentage of people evaluating their health as perfect or very good was significantly lower. Poles were also more likely to declare the presence of long-term health problems [7].

Taking into account the increasing number of people over 60 years of age, managing the healthcare services and ensuring the best possible quality of life is becoming an important civilization problem [8]. Aging is a natural and irreversible process. Yet, being physically active may mitigate or delay it. Regular physical effort is one of the most physiologically and economically effective ways to maintain and improve health and prevent chronic diseases and support treatment [9]. Moderate-intensity exercise lasting 30 to 60 minutes and performed three times a week may effectively support the treatment of obesity and musculoskeletal problems associated with it [10]. The research by Kadariya et al. proved that physical activity decreases the risk of depression and improves the quality of sleep [11]. A literature review by Li and Bin indicated that increasing physical activity may effectively improve insulin sensitivity in patients with metabolic syndrome, regulate lipid and glucose metabolism, lower blood pressure and reduce the incidence of metabolic syndrome [12]. Physical exercise is also an element of secondary physioprophylaxis of degenerative disease [9]. It should be noted that there is no universal exercise program for the elderly in general. Exercises should be adjusted to the individual needs of every patient, taking into account age, health and contraindications to a specific type of physical activity [11].

The results of the study by Wojtyniak and Goryński showed that in 2014 only $13.5 \%$ of people aged 50-59 did sport or recreational exercises, $12.2 \%$ of those aged $60-69$ and $8.5 \%$ of those aged $70-79$. Only 3.4\% of people over 80 years old were physically active [3]. In this study, the participants from Poland most often indicated physical activity in the form of working in the plot, cycling, dancing and flexibility training. The respondents from Ukraine most frequently declared work in the plot, cycling and flexibility training as well.

Physical activity is an effective method of primary and secondary physioprophylaxis for least 25 chronic diseases, with risk reductions typically in the range of 20-30\% [13]. People of all ages can benefit from physical activity. 
In Ukraine, $19 \%$ of the population is over 60 years of age and according to forecasts, in 2030 the group will constitute $23 \%$ of the population. Experts from the World Health Organization (WHO) consider low level of physical activity to be one of the most important risk factors for health and one of the main causes of mortality [14]. According to a sociological study conducted by Hakman, in Ukraine in 2017, the percentage of pensioners who practiced sport or performed any form of physical activity amounted to $17.6 \%$ men and $16.8 \%$ women [5]. In this study, the participants from Poland were significantly more likely to engage in physical activity than respondents from Ukraine. The participants from Poland most often indicated working in the plot (90.9\%), cycling (85.9\%) and dancing (52.9\%). Study participants from Ukraine most often worked in the plot (20.6\%), did gymnastics (7.8\%) and cycled (6.9\%). In Andreev's study of 73 Ukrainian residents, the most popular types of physical activity for men aged 60 years and older were walking (11\%), cycling (2.7\%), jogging, skiing (2\%), going to the gym (1.6\%) and swimming (1.2\%). Women indicated walking (11\%), swimming $(2.6 \%)$, going to the gym (1.4\%) and cycling (1.2\%) [15].

The study by Nieboer and Cramm confirmed the decrease in physical activity levels associated with the age of the subjects and the level of education. The role of social environment which should support the physical activity of seniors proved to be an important factor [16]. In this study, there was no correlation between the level of education and physical activity in both groups. However, in the group of study participants from Poland, it was noted that the older the respondents were, the less frequent was their physical activity.

Physical activity among seniors is an issue related to the prophylaxis of health risk factors, improving the quality of life and supporting recovery after illness. In this study, the participants from Poland indicated doctors, mass media, family acquaintances, web pages and physiotherapists as sources of knowledge on the topic of physioprophylaxis, while respondents from Ternopil indicated mainly doctors and nurses.

Physioprophylaxis in the form of physical activity combines physiotherapy with the health promotion of a healthy person and with the medical rehabilitation of a patient. Hence, the physiotherapist should be the main promoter and source of knowledge about physical activity. It's important that the decision-makers in the public healthcare sector understand the issue, ensure financial support and appreciate the role of physiotherapists in the promotion of physical activity so that physiotherapy can reach its full potential, far beyond its basic role in commercial services.

Lifestyle changes and regular physical exercises are important means of preventing and treating the occurrence of metabolic syndrome as well as cardiovascular and cerebrovascular diseases in middle-aged and elderly people [12]. A meta-analysis by Franco et al. revealed that some seniors still think that physical activity is not necessary or even potentially harmful. Others notice the benefits of physical activity but report a range of obstacles impeding physical exercise. Strategies to increase physical activity among seniors should include: raising awareness of the benefits and minimizing the perceived risks of physical activity as well as facilitating access to paid physical activity facilities [17]. Regular physical activity contributes to maintaining the functional independence of individuals, can prevent many diseases, improve functional capacity and limit the risk of falls and injuries [13].

\section{Conclusions}

1. Study participants from Poland more often engage in physical activity and perceive their health condition as good more frequently than the respondents from Ukraine.

2. Younger age and better health were the factors influencing the frequency and diversity of physical activity in the respondents from the Lublin Voivodeship.

3. Studies showed that there is a need to educate people above the age of 50 on the topic of physioprophylaxis through physical activity carried out professionally, preferably by physiotherapists.

\section{Disclosures and acknowledgments}

This work and paper were funded by the authors' own resources. The authors declare no conflicts of interest.

\section{References:}

1. Dąbrowski Z, Marchewka A, Żołądź JA. [Physiology of ageing]. 1st ed. Warszawa: Wydawnictwo Naukowe PWN; 2020 (in Polish).

2. Wieczorkowska-Tobis K, Kostka T, Borowicz AM. [Physiotherapy in geriatrics]. 1st ed. Warszawa: Wydawnictwo Lekarskie PZWL; 2011 (in Polish). 
3. Wojtyniak B, Goryński P. [Health situation of the Poland's population and its conditioning]. 2nd ed. Warszawa: Narodowy Instytut Zdrowia Publicznego-Państwowy Zakład Higieny; 2016 (in Polish).

4. Łysoń P. [Participation in sports and physical recreation in 2016]. Warszawa: GUS, Departament Badań społecznych i Warunków Życia; 2017 (in Polish).

5. Hakman A. Role of recreational-health activity for elderly people. International Conference on the 70th anniversary of sports medicine in the Republic of Moldova; 2017 Oct 12-14; Chisinau (Moldova).

6. [Attachment to the Resolution No. 384/IKRF of $16^{\text {th }}$ May 2019. Physioprophylaxis - definition and division] (in Polish).

7. Magda I, Kiełczewska A. [SHARE data from the perspective of quality of life assessment: people aged 50+ in Poland compared to the rest of Europe]. In: Myck M, Oczkowska M., editors. [50+ generation in Poland compared to the rest of Europe: activity, health and quality of life. The results of the SARE research]. 1st ed. Warszawa: Centrum Cenea; 2017 (in Polish).

8. Barnes JN. Exercise, cognitive function, and aging. Advances in Physiology Education. 2015; 39(2): 55-62. https://doi.org/10.1152/advan.00101.2014

9. Wurm S, Tomasik MJ, Tesch-Römer C. On the importance of a positive view on ageing for physical exercise among middle-aged and older adults: cross-sectional and longitudinal findings. Psychology \& Health. 2010; 25(1): 25-42. https://doi.org/10.1080/08870440802311314

10. Barrow DR, Abbate LM, Paquette MR, Driban JB, Vincent HK, Newman C, et al. Exercise prescription for weight management in obese adults at risk for osteoarthritis: synthesis from a systematic review. BMC Musculoskeletal Disorders. 2019; 20(1): 610-618. https://doi.org/10.1186/s12891-019-3004-3

11. Kadariya S, Gautam R, Aro A. Physical activity, mental health, and wellbeing among older adults in South and Southeast Asia: a scoping review. Bio Med. Research International. 2019; 11: 1-11. https://doi.org/10.1155/2019/6752182

12. Lu T, Bin L. Effects of physical activity and exercise on metabolic syndrome. Chinese Journal of Tissue Engineering Research. 2020; 24(2): 296-302.

13. Rhodes RE, Janssen I, Bredin SSD, Warburton DER, Bauman A. Physical activity: health impact, prevalence, correlates and interventions. Psychology \& Health. 2017; 32(8): 942-975. https://doi.org/10.1080/08870446.2017.1325486

14. Hakman AV, Balatska LV, Liasota TI. Effects of recreational and health-enhancing activity on the slowing of the body's aging. Physical Education, Sport, and Human Health. 2016; 9: 91-98.

15. Andrieieva O, Hakman A, Kashuba V, Vasylenko M, Patsaliuk K, Koshura A, et al. Effects of physical activity on aging processes in elderly persons. Journal of Physical Education and Sport. 2019; 9(4): 1308-1314.

16. Nieboer AP, Cramm JM. Enabling and disabling behaviors in the social environment are associated with physical activity of older people in the Netherlands. BMC Public Health. 2019; $19(1)$ : 361. https://doi.org/10.1186/s12889-019-6670-z

17. Franco MR, Tong A, Howard K, Sherrington C, Ferreira PH, Pinto RZ, et al. Older people's perspectives on participation in physical activity: a systematic review and thematic synthesis of qualitative literature. Br J Sports Med. 2015; 49(19): 1268-1276. https://doi.org/10.1136/bjsports-2014-094015 